\title{
Influence of Paper Mulberry Presence on Native Tree Species in Mabira Central Forest Reserve in Uganda
}

\author{
Alongo Boniface Byamalong Yamungu ${ }^{1,2}$ \\ ${ }^{1}$ Faculté des Sciences Economiques et de Gestion, Univeristé Espoir du Congo, Baraka, DR Congo \\ ${ }^{2}$ Department of Environmental Management, Makerere University, Kampala, Uganda \\ Email: byamalong@gmail.com, byamalong@caes.muk.ac.ug
}

How to cite this paper: Yamungu, A.B.B. (2020) Influence of Paper Mulberry Presence on Native Tree Species in Mabira Central Forest Reserve in Uganda. Open Access Library Journal, 7: e6399.

https://doi.org/10.4236/oalib.1106399

Received: May 7, 2020

Accepted: September 25, 2020

Published: September 28, 2020

Copyright $\odot 2020$ by author(s) and Open Access Library Inc.

This work is licensed under the Creative Commons Attribution International License (CC BY 4.0).

http://creativecommons.org/licenses/by/4.0/

\begin{abstract}
Mabira Central Forest Reserve in Uganda (MCFR) is facing biodiversity loss, especially other tree species in the paper mulberry dominated area due to Charcoal burning activities and the presence of paper mulberry (Broussonetia papyrifera). Paper mulberry (Broussonetia papyrifera) in the family Moraceae or Morus papyrifera is found mostly in the production zone identified as hotspot of biodiversity in Mabira central Forest reserve. Several studies in western and East Africa have indicated that paper mulberry consumes a lot of ground water which may reduce water availability for other species and lead to reduced growth level of native species around. This study has tried to investigate the influence of paper mulberry (Broussonetia papyrifera) presence on the loss of native tree species in buffer and production zone in MCFR. The study used $1 \mathrm{~km}$ transects and thirty plots of $20 \mathrm{~m} \times 10 \mathrm{~m}$ each. The index of Shannon and Simpson were used for species diversity and Jaccard similarity index was used for species similarity. The overall non-paper mulberry plant species or native tree species richness decreased significantly $(76.92 \%)(\mathrm{P}=$ 0.04 ) from the paper mulberry dominated area within the production zone of Mabira central forest reserve. The Shannon Wiener diversity index was 2.7 for production, 2.4 buffer and 0.8 for paper mulberry dominated area, which simply means that the paper mulberry dominated area was less diverse than the two other study sites. Seven hundred sixteen (716) trees were found in total with 56 different tree species where only one species which is paper mulberry was found 233 times and only 483 times of the 55 native species. Mabira central forest reserve is at risk of losing its natural forest in the years to come. This Impact is likely to increase with the increasing of paper mulberry planting. To avoid this the management should think on not planting paper mulberry trees within the natural forest and stop charcoal burning activities.
\end{abstract}




\section{Subject Areas}

Environmental Sciences

\section{Keywords}

Biodiversity, Mabira Forest, Native Trees Species, Paper Mulberry

\section{Introduction}

Broussonetia papyrifera, (Paper mulberry) either Kikambakamba or Nkulaido in local name is a flowering plant in the family Moraceae also known as Morus papyrifera, originated from Japan and Taiwan, found now worldwide. In Africa it is most found in West Africa (Ghana) and East Africa (Uganda) [1]. Across the continent in Uganda, throughout the Mabira Central Forest Reserve (Figure 1), paper mulberry has become a dominant plant along many of the forest's paths, roads, and edges, and has even begun to show up well into the forest [2]. Paper mulberry is one of the tree species growing fast and possible to attain the height starting from 10 to $21 \mathrm{~m}$ and the diameter at breast height of $70 \mathrm{~cm}$ with a round, spreading crown when growing under best conditions [3]. Broussonetia papyrifera can tolerate a wide range of climates, including humid tropical (monsoon), humid and sub-humid subtropical, and warm temperate areas. It can survive for about 3 - 4 month of dry season [4], but tends to be most abundant on soils that are generally moist. For nowadays, tree such as acacia and paper mulberry is the major concern for the world forest conservation. Paper mulberry is one of the best plant used for making paper worldwide, and helps some countries to generate more income from the sales of the paper mulberry trees to companies producing papers. Even though other factors such as, anthropogenic activities including charcoal burning, and tree harvesting are the major contributors of deforestation. Also, timber exploitation is the major contributor of losing natural forest as people are now planting tree producing good timber for increasing their income. This contributes to reducing the forest by the replacement of natural trees with artificial trees for timber and other related products from trees as well as Paper mulberry influence to the higher loss of natural forest.

The Paper Mulberry reduces animal pasture by 80 percent and affects food production. In parts of Busoga region where the tree has grown animals have no pasture and communities cannot plant any crops. According to Wanda et al., 2016 [5] a senior research Officer Aquatic weeds management at NaFIRRI, the shade created by the Paper mulberry tree cannot allow light to penetrate through it, which kills off other plants. This kind of plant "Paper mulberry" which is native to Eastern Asia has become an invader on several continents and in over a dozen countries including Uganda and Ghana in the African continent [6]. Some images for identification of paper mulberry fruits and leaves are shown in Figure 2 and Figure 3 respectively. 


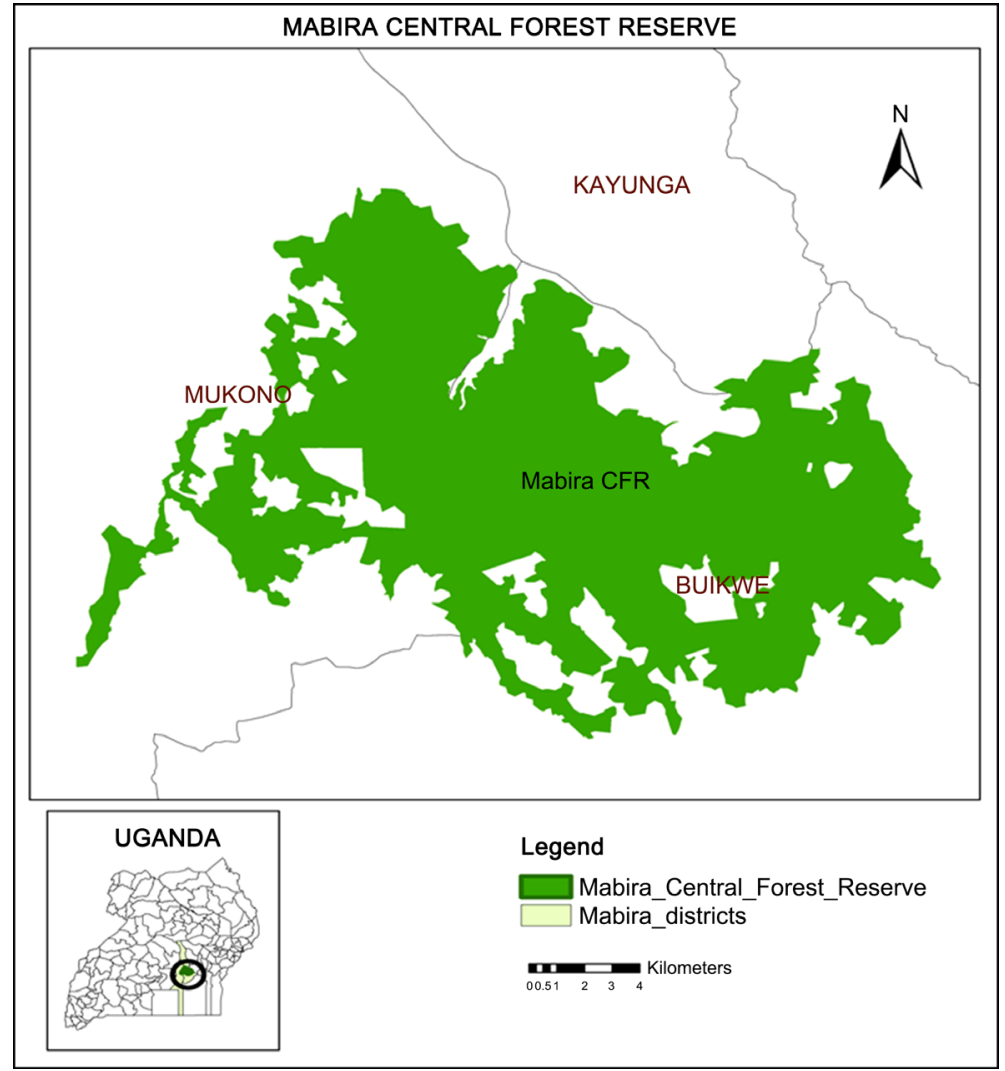

Figure 1. Map of the study area.

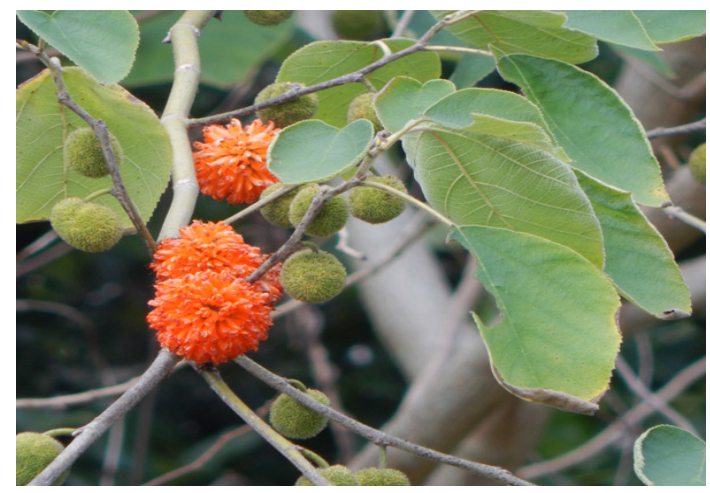

Figure 2. Paper mulbery fruits.

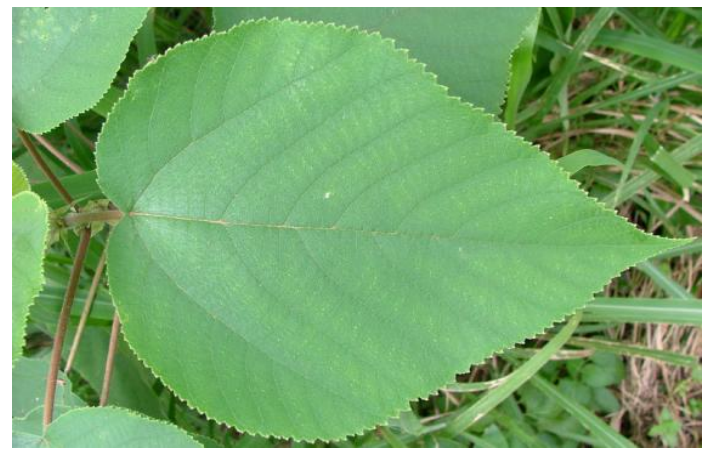

Figure 3. Paper mulbery leaves. 


\section{Material and Methods}

\subsection{Field Site Description}

This study was conducted in Mabira Central Forest Reserve is one of the Uganda's largest surviving Natural Forests covering an area of 306 square km. Mabira has Natural Habitat of 312 species of trees, home of 315 species of Birds, 218 Butterfly Species, 97 Moth Species, 23 Small Mammal Species. Many activities are doneincluding Forest Walks with over $68 \mathrm{~km}$ of well-developed trail length, Mountain Biking, Bird Watching, Environmental Education and Research, Camping and Picnics, Primate Watching, Butterfly Identification and General Forest Exploration.

Mabira boosts of 3 Bandas which can accommodate a maximum of 10 Guests at the Eco-Tourism Site near Najjembe Trading Centre. The Bandas are self-catering although some light meals can be prepared for you by the House keeper. There is also a Camping Ground near the Site for do-it-yourself caravans at a modest fee. Mabira Forest Lodge, a modern eco-friendly facility by the Alam Group of Companies is nearing completion. Mabira Central Forest Reserve is located on the main Kampala-Jinja Highway in Mukono District. It is $54 \mathrm{~km}$ from the City Centre of Kampala and $26 \mathrm{~km}$ from Jinja Town. The Eco-tourism Site is about half a kilometer from the road head along a short dirt road off the Najjembe trading center. The Forest is therefore accessible by all vehicles throughout the year [7].

The mature mixed forest type occupies the largest area and constitute $52 \%$ of the area of Mabira. It is indeed a mixed forest with 229 tree species [8] which have been noted to grow to timber size.

\subsection{Research Design and Sampling Strategy}

In this study, systematic sampling was employed in data collection, in selection of the study zones. Production zone and buffer zone are two zones were involved in this study. The production was divided into two areas, one named production zone and paper mulberry dominated area. One transects line was laid in each of the three areas. The transect direction was determined by use of campus as well as hand held Global Positioning System GPS for coordinates. The transect length was $1000 \mathrm{~m}$ in buffer zone and $1000 \mathrm{~m}$ in production zone and zone dominated by Paper mulberry. All trees with $\mathrm{DBH} \geq 5 \mathrm{~cm}$ were identified and $\mathrm{DBH}$ measured using caliper/diameter tap. A total of 30 rectangular plots, 7 in production zone with non-paper mulberry, 8 in buffer zone, 15 in production zone dominated by paper mulberry, with area of $200 \mathrm{~m}(20 \mathrm{~m} \times 10 \mathrm{~m})$ were demarcated on the transect lines at plot interval of $20 \mathrm{~m}$ in systematic alternate pattern by use of a measuring tape.

\subsection{Data Collection Methods}

This study was conducted in June, 2019 the transect methods was used to deter- 
mine the composition of the two different areas (production zone and buffer zone). One compartment was selected from Buffer zone and two compartments from Production zone. Three transects with the lengths of $1000 \mathrm{~m}$ or $1 \mathrm{~km}$ were selected within each compartment and fifteen plots of $20 \mathrm{~m} \times 10 \mathrm{~m}$ each with distance of $20 \mathrm{~m}$. The Geographical Positioning System (GPS) was used to help us to locate transect and the coordinates of each plot. Plot was systematically demarcated on the transect after every 50 meters. All trees with diameter at breast height $(\mathrm{DBH})$ equal and greater than $5 \mathrm{~cm}$ and height greater than $1.5 \mathrm{~m}$ above the ground was identified and recorded and their DBH measured. The NFA agents under the instruction of Mabira Central Forest Reserve helped us with the tree identification for the encountered tree species in local names and as researcher I managed to get the scientific names.

\subsection{Data Analysis}

To evaluate the species diversity, two diversity indices were used, the indices used were: Shannon-Wiener index (H0 1/4 Ps $\mathrm{i}^{1} \frac{1}{4} 1$ pinn $p^{i}$ ) and Simpson's index (D $\left.1 / 41=\mathrm{Ps} \mathrm{t}^{1 / 4} 1 p i \ln p i\right)$, where $s$ is the total number of species and $\mathrm{p}$ is the relative abundance of the $\boldsymbol{i}$ species. In contrast to direct measures of species richness, these indices take into account the relative abundances of species [9]. Species compositional similarity between the two areas, encroached forest and native forest was estimated using the Jaccard similarity index. The Jaccard similarity index uses species presence/absence data for two sample sets [10] (in this case zone types) and was calculated using this formula:

$$
S j=a / a+b+c
$$

where $\boldsymbol{a}$ is the number of species common to both quadrats/samples, $\boldsymbol{b}$ is the number of species in quadrat/sample 1 only, and $c$ is the number of species in quadrat/sample 2 only. Often the coefficient is multiplied by 100 to give a percentage similarity figure [11] for the species accumulation curves, and estimation of species diversity and compositional similarity [12]. ANOVA was used to test the statistical significance differences in mean DBH, density and basal area in the three areas. To determine if the DBH-size class distribution of individuals of plants between different areas was significantly different after testing for normality the Hutcheson t-test was used. The statistically significance levels are reported at $\mathrm{P} \geq 0.05$ [13].

\subsection{Result}

\subsubsection{Species Abundance, Richness, Diversity and Community Similarity Species abundance and richness}

A total of 716 plants were found in all zones including 233 of paper mulberry and 483 trees of other non-paper mulberry species or native tree species. In all three different zones 56 different species were identified, in production zone was the most diverse with 204 individuals of 40 different species, followed by Buffer zone with 245 individuals were found of 32 different species and Paper mulberry 
dominated area with 267 individuals of 13 species, the last being the first in species dominance. Moreover, the production zone was the first in terms of species richness having 40 different species or 69.6 percent $(69.6 \%)$ of the study area followed by buffer zone and paper mulberry dominated area being the last. In terms of abundance Paper mulberry dominated area was most abundant site with a total of 268 individuals or $37.43 \%$ followed by buffer zone with 245 plants or $34.21 \%$ of total individuals identified and the production zone was last abundant site with 207 individuals or $28.91 \%$ (Table 1).

\subsubsection{Species Diversity}

Species diversity was higher in production zone followed by buffer and least in paper mulberry. Shannon-Weiner diversity index is high when it is above 3.0, medium when it is between 2.0 and 3.0, low when between 1.0 and 2.0 and very low when it is smaller than 1.0 [14]. For this study, the Shannon Weiner diversity index was 2.7 for production zone, 2.4 buffer zone and 0.8 for paper mulberry zone which simply means that the production zone was more diverse than the two others. Jaccard similarity index of $(s / s 1+s 2+s)$ was used to evaluate the similarity the results were 0.17 for Production and Paper mulberry, 0.25 for Buffer and Paper mulberry zone. The species diversity is most seen in the production zone where in the 57 species identified it accounts 40 different species followed by buffer zone with 31 different species and the last one in term of species diversity is the paper mulberry dominated area within the production zone with only 12 different species. This means in the paper mulberry dominated area there is a drastic loss of natural tree species as shown in Figure 4.

\subsubsection{Species Similarity}

Shannon-Weiner diversity index is high when it is above 3.0, medium when it is between 2.0 and 3.0, low when between 1.0 and 2.0 and very low when it is smaller than 1.0 [15]. The Shannon wiener diversity index was 2.7 for production, 2.4 buffer and 0.8 for paper mulberry. Jaccard similarity index of $(\mathrm{s} / \mathrm{s} 1+\mathrm{s} 2$ $+s$ ) was used to evaluate the similarity and the results were as follows: 0.17 for Production and Paper mulberry, 0.25 for Buffer and Paper mulberry zone.

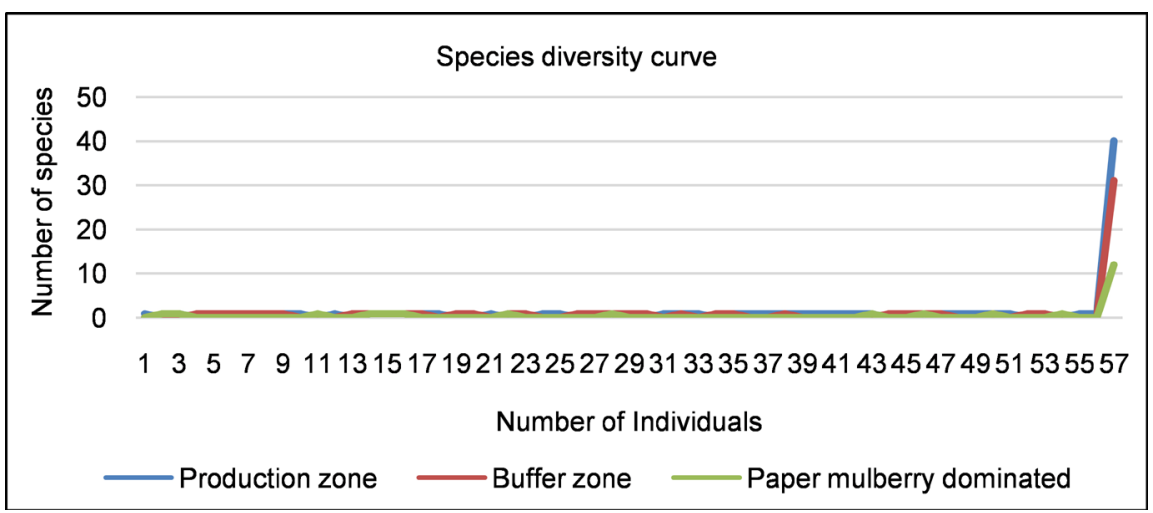

Figure 4. Species diversity. 
Table 1. Abundance of tree species in three different study sites of Mabira central Forest Reserve in Uganda.

\begin{tabular}{|c|c|c|c|c|}
\hline Species & Buffer Zone & $\begin{array}{l}\text { Production } \\
\text { Zone }\end{array}$ & $\begin{array}{l}\text { Paper Mulberry } \\
\text { Dominated Area }\end{array}$ & Total \\
\hline Afzelia africana & 0 & 1 & & 1 \\
\hline Agave sisalana & 0 & 1 & & 1 \\
\hline Olea welwitschii & 1 & & & 1 \\
\hline Albizia ferruginea & 4 & 1 & & 5 \\
\hline Alibizia spp. & & & 2 & 2 \\
\hline Alstonia boonei & 1 & & 1 & 2 \\
\hline Antaris toxicaria & 13 & 7 & 1 & 21 \\
\hline Artocarpus heterophyllus & 0 & & 1 & 1 \\
\hline Balanites wilsoniana & 2 & & & 2 \\
\hline Blighia unijugata & 3 & 3 & 1 & 7 \\
\hline Bosqueia phoberos & 0 & 2 & & 2 \\
\hline Bridelia micrantha & 0 & 1 & & 1 \\
\hline Broussonetia papyrifera & 11 & 1 & 221 & 233 \\
\hline C. africana & 0 & 1 & & 1 \\
\hline Canarium schweinfurthii & 0 & 1 & & 1 \\
\hline Celtis africana & 3 & 2 & & 5 \\
\hline Celtis durandai & 1 & & & 1 \\
\hline Celtis mildbraedii & 23 & 55 & 11 & 89 \\
\hline Celtis zenkeri & & & 1 & 1 \\
\hline Chrysophyllum albidum & 1 & 6 & & 7 \\
\hline Coffea canephora & 0 & 1 & & 1 \\
\hline Dichrostachys cinerea & 4 & 4 & 2 & 10 \\
\hline Diospoyros absynica & 2 & 1 & & 3 \\
\hline Euphorbia hirta L & 26 & 5 & & 31 \\
\hline Ficus carparsis & 0 & 1 & 5 & 6 \\
\hline Ficus exasperata & 1 & & & 1 \\
\hline Ficus mucuso & & & 2 & 2 \\
\hline Funtumia africana & 69 & 26 & 2 & 97 \\
\hline Harungana madagascariensis Lam. Ex Poir. & 0 & 1 & & 1 \\
\hline Holoptelea grandis & 7 & 3 & & 10 \\
\hline Justicia heterocarpa & 0 & 1 & 17 & 18 \\
\hline Khaya anthotheca & 0 & 1 & & 1 \\
\hline
\end{tabular}




\section{Continued}

\begin{tabular}{|c|c|c|c|c|}
\hline Khaya spp. & 1 & 2 & & 3 \\
\hline Erythrophleum suaveolens & 2 & 4 & & 6 \\
\hline Macaranga kilimandscharica & 0 & 3 & & 3 \\
\hline Maesopsis eminii & 1 & & & 1 \\
\hline Mondia whytei & 0 & 1 & & 1 \\
\hline Makhemia lutemia & 1 & & & 1 \\
\hline Margaritaria descodius & 2 & 9 & & 11 \\
\hline Markhamia lutea (Benth.) K. schum & 1 & & & 1 \\
\hline Milicia excelsa & 1 & & & 1 \\
\hline Monodora melistica & 0 & 1 & & 1 \\
\hline Morus mesozygia & 0 & 1 & & 1 \\
\hline Musanga cecropioides & 0 & 1 & & 1 \\
\hline Oxyanthus speciosus & 13 & 3 & & 16 \\
\hline Pachystela brevipes & 4 & 10 & & 14 \\
\hline Podocarpus latifolius & 1 & & & 1 \\
\hline Prunus africana & 1 & & & 1 \\
\hline Sapium ellipticum & 1 & 6 & & 7 \\
\hline Tabernaemontana pachysiphon & 0 & 1 & & 1 \\
\hline Teclare nobilis & 36 & 28 & & 64 \\
\hline Trema orientalis & 6 & 1 & & 7 \\
\hline Trichilia dregeana & 0 & 1 & & 1 \\
\hline Trichilia rubescens & 0 & 5 & & 5 \\
\hline Trimeria grandifolia & 2 & & & 2 \\
\hline Warburgia ugandensis & 0 & 1 & & 1 \\
\hline Total per area & 245 & 204 & 267 & 716 \\
\hline
\end{tabular}

Source: Survey June, 2019.

\subsubsection{Structural Characteristics}

The DBH-size class distribution of the number of individuals of non-paper mulberry plants in the three different zones is shown in Figure 5. Significant differences in the distribution of non-paper mulberry plants in the DBH-size classes were found between the production zone and the paper mulberry dominated area (Hutcheson t-test, P-value $<0.05$ ), and between buffer zone and the paper mulberry dominated area. 55\% of the species belong to the first class of 5 $10,18 \%$ belong to $10-15,8.4 \%$ for $15-20,6 \%$ belong to $20-25,3.4 \%$ belong to $25-30,2.2 \%$ belong to $30-35,1 \%$ belong to $35-40,2 \%$ belong to $40-45,1 \%$ belong to $45-50,0.7 \%$ belong to $50-55,1.7 \%$ belong to $>55$. This indicated a high frequency distribution in a low diameter class of $5-10$, and decreased 


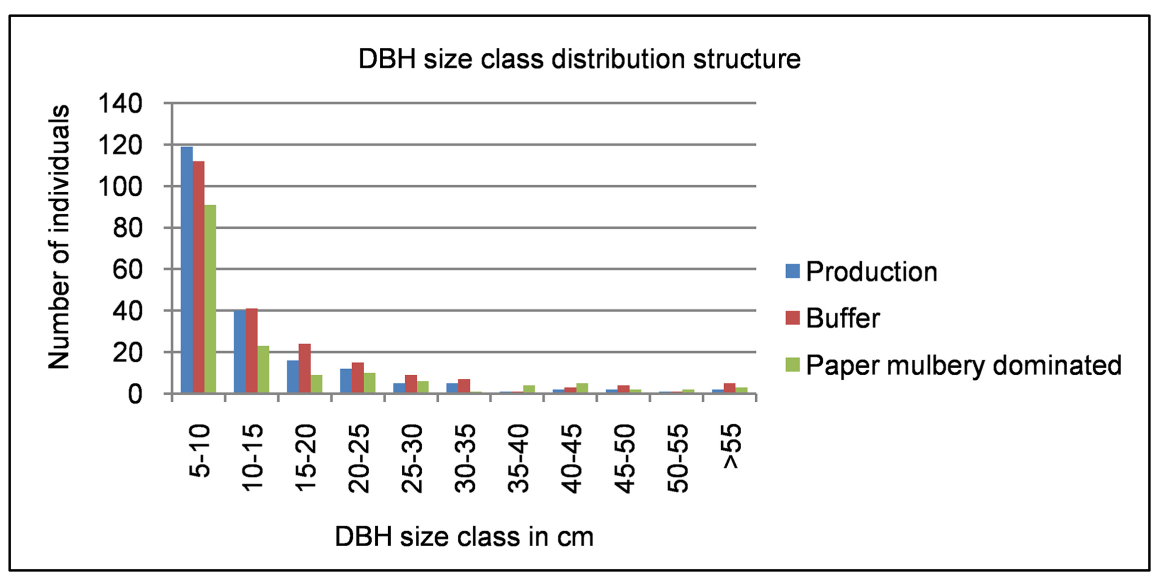

Figure 5. Size class distribution structure.

towards the higher classes. However, from the middle classes of 35 - 40, 40 - 45, species in buffer and production zone tend to disappear than paper mulberry. The significance in abundance was at $P$ value $0.04,0.05$ critical level at $95 \%$ confidence level between buffer and paper mulberry dominated zone as provided in Figure 5.

\subsection{Discussion}

The results in this study show that Paper mulberry known locally as "Kikambakamba or nkulaido" is not found in the natural forest where natural plants are more abundant and it is more dominant in its zone where natural plants species are rare and likely to disappear. Species richness and composition is continually decreasing in the paper mulberry dominant area compare to native forest. The results from Shannon Weiner diversity index show, medium species diversity in production zone and Buffer and very low diversity in paper mulberry zone. Broussonetia papyrifera showed dynamic growth, extending over large areas in the moist semi-deciduous forest zone to the exclusion of many other plant species. Thus, invaded areas have considerably low herbaceous and woody species richness and diversity. Therefore, plant species diversity decreases with dominance of Broussonetia papyrifera [15]. The diameter class structure showed nearly J-shape with a decline in density from 7 middle class. An indicator of over harvesting of the forest especially of trees with $\mathrm{DBH}$ ranging from $35 \mathrm{~cm}$ to $55 \mathrm{~cm}$, in production zone and buffer than in paper mulberry zone which is favoring paper mulberry to multiply aggressively party due to the favorable climatic condition and fertile soils.

\section{Conclusion}

Broussonetia papyrifera (L.) Vent. (Paper mulberry) is the major contributor of nature forest loss, as it consumes a lot of water and preventing other natural plants to get the necessary water and nutrient for regeneration growth and foods for plant that causes other species to die and leave the space to the dominant 
plant. Paper mulberry, because of its high rate of water consumption compare to other tree species, if not planted in its own zone or mixed with other natural plants will lead to the loss of natural forest which can increase the tree harvesting from the restricted area because of the scarcity in the production zone. Paper mulberry has an influence on other tree species regeneration, so it should not be mixed with other tree species in case that we want to conserve our natural forest.

\section{Recommendation}

As shown in the result above of this study, the paper mulberry has dominance on other tree species with the same area, I would recommend that this dominance and invasion should be regularly monitored and checked to help in the protection of the other species. Likewise, for not losing the natural trees, the paper mulberry should not be mixed with other trees species; it should be planted in its own area to avoid the drastic loss of natural forest that would occur when grown together with other tree species. Most research should be done on paper mulberry dominance to help the forest management officials to get accurate relevant information for sustainable use of natural forest and maintain its ecological status.

\section{Acknowledgements}

I am gratefully recognizing the Environmental Management Department, Makerere University for organizing and funding this study. The author acknowledges all participants who contributed to this work including fellow students, Mabira Central Forest Reserve Management team and Reviewers for their paramount comments. The author is further thankful to all the academic team of the environmental Management department/Makerere University, namely Professor John Tabuti, Professor Frank Kansiime, Associate Professor Vincent Muwanika, Dr Justine J. Namaalwa (Head of Department), Dr Anthony Egeru, Dr Kenneth Nyombi and others whose names are not mentioned for their time and capacity building before and during the field trip in Mabira Central Forest Reserve for data collection. Last but not least, the author is thankful to Professor Majaliwa Mwanjalolo J. G for his moral and technical support during the study journey at Makerere University.

\section{Conflicts of Interest}

The author declares no conflicts of interest regarding the publication of this paper.

\section{References}

[1] Crushes, S. (2012 and 2016) Invasive Plant Risk Assessment Department of Agriculture and Fisheries Biosecurity Queensland.

[2] Keith Child (2009) Civil Society in Uganda: The Struggle to Save the Mabira Forest Reserve. Journal of Eastern African Studies, 3, 240-258. 
https://doi.org/10.1080/17531050902972659

[3] Apetorgbor, M.M. and Bosu, P.P. (2011) Occurrence and Control of Paper Mulberry (Broussonetia papyrifera) in Southern Ghana.

[4] Whistler, W. and Elevitch, C. (2020) Casuarina equisetifolia (Beach She-Oak) C. cunninghamiana (River She-Oak).

[5] Masifwa, W.F., Matuha, M. and Amondito, B. (2016) Status of Kariba Weed (Salvinia molesta) Infestation, Its Impacts and Control Options on Uganda's Water Systems.

[6] Morgan, E.C. and Overholt, W.A. (2014) Wildland Weeds: Paper Mulberry, Broussonetia papyrifera.

[7] Obua, J., Agea, J.G. and Ogwal, J.J. (2010) Status of Forests in Uganda. African Journal of Ecology, 48, 853-859. https://doi.org/10.1111/j.1365-2028.2010.01217.x

[8] Ministry of Water and Environment (2017) 2020 Republique of Uganda, Revised Forest Management Plan for Mabira Central Forest Reserves.

[9] Asase, A., Ofori-Frimpong, K. and Ekpe, P.K. (2009) Impact of Cocoa Farming on Vegetation in an Agricultural Landscape in Ghana. African Journal of Ecology, 48, 338-346. https://doi.org/10.1111/j.1365-2028.2009.01112.x

[10] Kenrose, S. (2016) Statistics Handbook. http://www.StatisticsHowTo.com

[11] Colwell, R. (2005) ESTIMATES: Statistical Estimation of Species Richness and Shared Species from Samples.

[12] König, C., Weigelt, P. and Kreft, H. (2017) Dissecting Global Turnover in Vascular Plants. Global Ecology and Biogeography, 26, 228-242.

https://doi.org/10.1111/geb.12536

[13] R Core Team (2017) R: A Language and Environment for Statistical Computing. R Foundation for Statistical Computing, Vienna. https://www.R-project.org

[14] Atsbha, T., Desta, A.B. and Zewdu, T. (2019) Woody Species Diversity, Population Structure, and Regeneration Status in the Gra-Kahsu Natural Vegetation, Southern Tigray of Ethiopia. Heliyon, 5, e01120. https://doi.org/10.1016/j.heliyon.2019.e01120

[15] Bosu, P.P., Apetorgbor, M.M., Nkrumah, E.E. and Bandoh, K.P. (2013) The Impact of Broussonetia papyrifera (L.) Vent. on Community Characteristics in the Forest and Forest-Savannah Transition Ecosystems of Ghana. African Journal of Ecology, 51, 528-535. https://doi.org/10.1111/aje.12063 


\section{Appendix (Abstract and Keywords in French)}

\section{Resume}

La réserve forestière centrale de Mabira en Ouganda (MCFR) fait face à une perte de biodiversité, en particulier d'autres espèces d'arbres dans la zone dominée par le mûrier à papier en raison des activités de brûlage du charbon de bois et de la présence de mûrier à papier (Broussonetia papyrifera). Le mûrier à papier (Broussonetia papyrifera) dans la famille Moraceae ou Morus Papyrifera se trouve le plus dans la zone de production identifiée comme point chaud de la biodiversité dans la réserve forestière centrale de Mabira. Plusieurs études en Afrique de l'Ouest et de l'Est ont indiqué que le mûrier à papier consomme beaucoup d'eau souterraine, ce qui peut réduire la disponibilité en eau pour d'autres espèces et conduire à un niveau de croissance réduit des espèces indigènes environnantes. Cette étude a tenté d'étudier l'influence de la présence de mûrier à papier (Broussonetia papyrifera) sur la perte d'espèces d'arbres indigènes dans la zone tampon et de production du MCFR. L'étude a utilisé des transects de $1 \mathrm{~km}$ et trente parcelles de $20 \mathrm{~m} \times 10 \mathrm{~m}$ chacune. L'indice de Shannon et Simpson a été utilisé pour la diversité des espèces et l'indice de similarité de Jaccard a été utilisé pour la similitude des espèces. La richesse globale en espèces de mûriers autres que le papier ou la richesse en espèces d'arbres indigènes a diminué de manière significative $(76.92 \%)(\mathrm{P}=0.04)$ dans la zone dominée par le mûrier à papier dans la zone de production de la réserve forestière centrale de Mabira. L'indice de diversité de Shannon Wiener était de 2.7 pour la production, 2.4 tampons et 0.8 pour la zone dominée par le mûrier à papier, ce qui signifie simplement que la zone dominée par le mûrier à papier était moins diversifiée que les deux autres sites d'études. Sept cent seize (716) arbres ont été trouvés au total avec 56 espèces d'arbres différentes où une seule espèce qui est le mûrier à papier a été trouvée 233 fois et seulement 483 fois sur les 55 espèces indigènes. La réserve forestière centrale de Mabira risque de perdre sa forêt naturelle dans les années à venir. Cet impact est susceptible d'augmenter avec l'augmentation des plantations de mûriers à papier. Pour éviter cela, la direction devrait penser à ne pas planter de mûriers à papier dans la forêt naturelle et arrêter les activités de brûlage du charbon de bois.

\section{Mots Clés}

Biodiversité, Espèces D’arbres Indigènes, Forêt de Mabira, Mûrier à Papier 